\title{
REG I $\alpha$ gene expression is linked with the poor prognosis of lung adenocarcinoma and squamous cell carcinoma patients via discrete mechanisms
}

\author{
MICHITAKA KIMURA $^{1}$, HIROSHI NAITO ${ }^{1}$, TAKASHI TOJO ${ }^{1}$, ASAKO ITAYA-HIRONAKA ${ }^{2}$, YOSHIKO DOHI ${ }^{2}$, \\ MAMIKO YOSHIMURA $^{1}$, KAN-ICHI NAKAGAWARA ${ }^{3}$, SHIN TAKASAWA $^{2}$ and SHIGEKI TANIGUCHI ${ }^{1}$ \\ Departments of ${ }^{1}$ Thoracic and Cardiovascular Surgery and ${ }^{2}$ Biochemistry, Nara Medical University, \\ Kashihara, Nara 634-8522; ${ }^{3}$ Nihon Gene Research Laboratories Inc., Sendai, Miyagi 983-0005, Japan
}

Received June 27, 2013; Accepted August 20, 2013

DOI: 10.3892/or.2013.2739

\begin{abstract}
The aim of the present study was to evaluate the effects of the REG I $\alpha$ and REG I $\beta$ genes on lung cancer cell lines, and thereafter, the expression of $R E G$ family genes (REG I $\alpha, R E G I \beta, R E G I I I, H I P / P A P$ and REG IV) in lung cancer in relation to patient prognosis was evaluated. Lung adenocarcinoma (AD) and squamous cell carcinoma (SCC) cell lines expressing REG I $\alpha$ or REG I $\beta$ (HLC-1 REG I $\alpha / \mathrm{I} \beta$ and EBC-1 REG I $\alpha / \mathrm{I} \beta$ ) were established, and cell number, cell invasive activity, and anchorage-independent cell growth were compared with these variables in the control cells. The expression levels of $R E G$ family genes were evaluated by real-time RT-PCR in surgically resected lung cancers, and disease-specific survival (DSS) curves were generated. The HLC-1 REG I $\alpha / I \beta$ cell line showed significant increases in cell number and anchorage-independent cell growth compared with the control cells. EBC-1 REG I $\alpha / \mathrm{I} \beta$ cells showed significant increases in cell invasive activity and anchorageindependent cell growth as compared with the control cells. Except for the REG I $\beta$ gene, expression of other REG family genes was observed in the surgically resected samples; however, DSS was significantly worse only in stage I patients who were positive for $R E G I \alpha$ expression than in patients who were negative for $R E G I \alpha$ expression. The effects of $R E G I \alpha$ on $\mathrm{AD}$ and SCC cells were different in the in vitro study, and a correlation between REG I $\alpha$ expression and patient prognosis was noted in the in vivo study. Therefore, overexpression of
\end{abstract}

Correspondence to: Dr Hiroshi Naito, Department of Thoracic and Cardiovascular Surgery, Nara Medical University, 840 Shijocho, Kashihara, Nara 634-8522, Japan

E-mail: naitoh@naramed-u.ac.jp

Abbreviations: AD, adenocarcinoma; DSS, disease-specific survival; FFPE, formalin-fixed paraffin-embedded; NSCLC, nonsmall cell lung cancer; Reg, regenerating gene; SCC, squamous cell carcinoma

Key words: REG family genes, REG Ia gene, lung cancer, prognostic factor, gene expression
$R E G I \alpha$ is a risk factor for poor prognosis caused by discrete mechanisms in AD and SCC patients.

\section{Introduction}

In Japan, the number of lung cancer patients is increasing and lung cancer has become the leading and the second largest cause of cancer-related mortality in men and women, respectively (1). Since the improvement in diagnostic technologies for lung cancer, an increasing number of patients are being diagnosed in the early stages of the disease. In cases where non-small cell lung cancer (NSCLC) is diagnosed in the early stages, favorable prognoses have been reported after treatment with lobectomy (2-5), and lobectomy without any adjuvant therapy is an approved standard of therapy for these patients (3-5). However, we often encounter rapid tumor progression after lobectomy, even in these patients. If, therefore, the likelihood of this rapid progression could be predicted, it would be reasonable to initiate adjuvant therapy in advance.

The regenerating gene ( $R e g$ ) was originally discovered in the regeneration of pancreatic $\beta$-cells (6-8). There are currently five genes in the $R E G$ family found in humans ( $R E G I \alpha$, REG I $\beta, R E G I I I, H I P / P A P$ and REG IV) (9), encoding a growth factor family of proteins involved not only in regeneration of damaged tissues but also in the growth of various types of cancers, including gastrointestinal cancer, cholangiocarcinoma, pancreatic cancer, breast cancer and prostate cancer (10-27). A correlation between REG I $\alpha$ expression and poor prognosis has also been reported in NSCLC (28). While studies have indicated that poor prognosis in patients expressing REG I $\alpha$ appears to be due to an increased cell number in gastric and pancreatic cancers $(13,26)$, the impact of REG I $\alpha$ on cancer cells has not been examined in NSCLC.

In the present study, the effects of the expression of $R E G I \alpha$ and $R E G I \beta$, which has a similar structure to $R E G I \alpha$ and seems to have an identical function to REG $I \alpha$, on adenocarcinoma (AD) and squamous cell carcinoma (SCC) cells were examined in vitro. In addition, we investigated the correlation between expression of REG family genes and the prognosis of $\mathrm{AD}$ and SCC patients. 
Table I. Primers and probes for real-time RT-PCR.

\begin{tabular}{|c|c|c|}
\hline Gene (Accession no.) & & Sequence \\
\hline$\beta$-actin (NM_001101) & $\begin{array}{l}\text { Forward: } \\
\text { Reverse: } \\
\text { Probe: }\end{array}$ & $\begin{array}{l}\text { 5'-GCGAGAAGATGACCCAGA-3' } \\
\text { 5'-CAGAGGCGTACAGGGATA-3' } \\
\text { 5'-FAM-ACAGCCTGGATAGCAACGTACATGGCT-TAMRA-3' }\end{array}$ \\
\hline REG I $\alpha$ (NM_002909) & $\begin{array}{l}\text { Forward: } \\
\text { Reverse: } \\
\text { Probe: }\end{array}$ & $\begin{array}{l}\text { 5'-AGGAGAGTGGCACTGATGACTT-3' } \\
\text { 5'-TAGGAGACCAGGGACCCACTG-3' } \\
\text { 5'-FAM-TGGCCTCCATGACCCCAAAAAGAAC-TAMRA-3' }\end{array}$ \\
\hline REG I $\beta$ (NM_006507) & $\begin{array}{l}\text { Forward: } \\
\text { Reverse: } \\
\text { Probe: }\end{array}$ & $\begin{array}{l}\text { 5'-GCTGATCTCCTCCCTGATGTTC-3' } \\
\text { 5'-GGCAGCTGATTCGGGGATTA-3' } \\
\text { 5'-FAM-TGTCTCTGAGCCAAGGCCAGGAGTCCCA-TAMRA-3' }\end{array}$ \\
\hline REG III (AB161037) & $\begin{array}{l}\text { Forward: } \\
\text { Reverse: } \\
\text { Probe: }\end{array}$ & $\begin{array}{l}\text { 5'-GAATATTCTCCCCAAACTG-3' } \\
\text { 5'-GAGAAAAGCCTGAAATGAAG-3' } \\
\text { 5'-FAM-CCTACCTGACTACCTTGTCATGATCCTCC-TAMRA-3' }\end{array}$ \\
\hline HIP/PAP (NM_138937) & $\begin{array}{l}\text { Forward: } \\
\text { Reverse: } \\
\text { Probe: }\end{array}$ & $\begin{array}{l}\text { 5'-AGAGAATATTCGCTTAATTCC-3' } \\
\text { 5'-AATGAAGAGACTGAAATGACA-3' } \\
\text { 5'-FAM-CCAACCTGACCACCTCATTCTTATCTTTC-TAMRA-3' }\end{array}$ \\
\hline REG IV (AY007243) & $\begin{array}{l}\text { Forward: } \\
\text { Reverse: } \\
\text { Probe: }\end{array}$ & $\begin{array}{l}\text { 5'-ATCCTGGTCTGGCAAGTC-3' } \\
\text { 5'-CGTTGCTGCTCCAAGTTA-3' } \\
\text { 5'-FAM-CTGTGCTGAGATGAGCTCCAATAACAACTT-TAMRA-3' }\end{array}$ \\
\hline
\end{tabular}

\section{Materials and methods}

Human lung cancer cell lines. The HLC-1 human lung adenocarcinoma cell line and the EBC-1 human squamous cell carcinoma cell line were obtained from Riken BioResource Center (Tsukuba, Japan). HLC-1 and EBC-1 cells were maintained in Ham's F12 and minimum essential medium (MEM), respectively. No expression of any of the REG family genes was confirmed in these cells by real-time RT-PCR.

Establishment of stable transfectants for REG I $\alpha$ and REG I $\beta$. We established two cell lines expressing the REG I $\alpha$ or the $R E G$ I $\beta$ gene in HLC-1 and EBC- 1 cells and one mock-transfected cell line as a control for each cell type. The expression vectors or a control vector (without insert DNA) were then transfected into HLC-1 or EBC-1 cells by electroporation (17). Stable transfectants were selected after 2 weeks of culture with $500 \mu \mathrm{g} / \mathrm{ml}$ Geneticin ${ }^{\circledR}$ (Gibco, Carlsbad, CA, USA). REG I $\alpha$ or REG I $\beta$ expression was confirmed by real-time RT-PCR and immunoblot analysis of the culture medium, as previously described (17). The resulting Geneticin-resistant clones were designated as HLC-1 REG I $\alpha-1,-2$; HLC-1 REG I $\beta-1,-2$; HLC-1 mock; EBC-1 REG I $\alpha-1,-2$; EBC-1 REG I $\beta-1,-2$; and EBC-1 mock.

Cell number, cell invasive capacity and anchorage-independent cell growth. For evaluation of cell growth in the HLC-1 and EBC-1 cell lines, cells were cultured in Ham's F12 or MEM containing 1 or $0.5 \%$ FBS, respectively. The cell number for the HLC-1 cells was determined using a Cell Counting Kit-8 (Dojindo, Mashikimachi, Japan) on 1, 3, 5 and 7 days of culture, and that for EBC-1 was monitored on 0, 1, 2 and 3 days of culture. Increases in the cell number were expressed as the percentage of the cell number at culture day 1 or 0 , respectively. Cell invasive activity was monitored using a Cultrex 96 Well BME Cell Invasion assay (Trevigen, Gaithersburg, MD, USA). To evaluate anchorage-independent cell growth, cells $\left(1.75 \times 10^{3}\right)$ were plated into 12 -well plates in culture medium containing $0.35 \%$ agar on top of $0.5 \%$ agar, prepared in the same medium. The plates were incubated at $37^{\circ} \mathrm{C}$ for 16 days. Colonies were stained with $0.005 \%$ crystal violet for $1 \mathrm{~h}$. Colonies, containing at least 50 cells, were counted.

Patients. Fifty-one AD and 23 SCC patients, who underwent surgery at Nara Medical University Hospital from 2004 to 2007, were enrolled. The present study was approved by the Ethics Committee of the Nara Medical University School of Medicine. Fifty-one were male and 23 were female, and the mean age was $68.3 \pm 1.1$ years. Forty-six patients (AD, 32 patients; SCC, 14 patients) were in pathological stage I, 8 patients (AD, 2; SCC, 6) were in stage II and 20 patients (AD, 17; SCC , 3) were in stage III. Sixty-eight patients (AD, 47; SCC, 21) underwent complete resection and the remaining 6 patients (AD, 4; SCC, 2) in stage III received incomplete resection because of the extensive invasion of the tumors into the surrounding organs.

Real-time RT-PCR of surgical tissue samples. Samples (tumor and normal lung tissues) were collected immediately after lung resection (surgical sample), and frozen in liquid nitrogen until RNA isolation. Total RNA was isolated for real-time reverse transcription-polymerase chain reaction (real-time 
Table II. Characteristics of the lung cancer patients with complete resection.

\begin{tabular}{|c|c|c|c|c|c|c|}
\hline & \multicolumn{3}{|c|}{ Adenocarcinoma } & \multicolumn{3}{|c|}{ Squamous cell carcinoma } \\
\hline & \multicolumn{3}{|c|}{ REG I $\alpha$ gene expression } & \multicolumn{3}{|c|}{$R E G I \alpha$ gene expression } \\
\hline & Positive & Negative & P-value & Positive & Negative & P-value \\
\hline \multicolumn{7}{|l|}{ Gender } \\
\hline Male & 3 & 25 & 0.64 & 4 & 15 & 0.97 \\
\hline Female & 2 & 17 & & 1 & 1 & \\
\hline Age (years) & $72.0 \pm 2.2$ & $66.0 \pm 1.5$ & 0.15 & $73.0 \pm 2.7$ & $71.6 \pm 2.0$ & 0.72 \\
\hline \multicolumn{7}{|l|}{ Tumor stage } \\
\hline I & 4 & 28 & 0.92 & 3 & 11 & 0.86 \\
\hline II and III & 1 & 14 & & 2 & 5 & \\
\hline
\end{tabular}

RT-PCR), as previously described $(27,28)$. The primers and probes (Table I) were synthesized by Nihon Gene Research Laboratories (Sendai, Japan). Real-time RT-PCR was then carried out using TaqMan ${ }^{\circledR}$ Universal PCR Master Mix in an ABI PRISM ${ }^{\circledR} 7700$ Sequence Detection system (Applied Biosystems, Foster City, CA, USA). Expression of $R E G$ family genes was normalized with respect to $\beta$-actin. The cut-off levels for expression of each gene were set at the average $+3 \mathrm{SD}$ expression of the normal lung tissues. The expression of each $R E G$ family gene, which was higher or lower than the cut-off level, was defined as high or weak, respectively, and the absence of the expression of each gene was defined as no expression. For analysis of the correlation between the expression of each gene and prognosis, patients with high expression were defined as positive, and those with weak or absence of expression were defined as negative.

Real-time RT-PCR of formalin-fixed paraffin-embedded (FFPE) samples. Total RNA was isolated from FFPE tissue specimens (AD, 10; SCC, 8, randomly selected) using the RNeasy FFPE kit (Qiagen, Hilden, Germany) and reverse transcribed as described above. Real-time PCR was performed using KAPA SYBR ${ }^{\circledR}$ FAST qPCR Master Mix (Kapa Biosystems, Boston, MA, USA) and the Thermal Cycler Dice Real-Time System (Takara, Otsu, Japan) as previously described (29-31).

Disease-specific survival. Patient death in the progression of lung cancer was defined as the end point. Kaplan-Meier survival curves for disease-specific survival (DSS) were constructed according to the expression of REG I $\alpha$ or REG IV genes.

Statistics. Data are expressed as the mean \pm standard error of the mean (SEM), and cell number, cell invasive activity and anchorage-independent cell growth were compared by unpaired t-tests. Comparison of clinicopathological parameters according to the expression of the REG I $\alpha$ gene was carried out by Chi-squared analyses. Kaplan-Meier survival curves for DSS were compared using the log-rank test. Correlations of the expression levels of the REG I $\alpha$ gene from surgical and
FFPE samples were analyzed using Pearson non-parametric tests. A P-value of $<0.05$ was considered to indicate a statistically significant result.

\section{Results}

Effects of the transfection of REG I $\alpha$ and REG I $\beta$ on cell number, cell invasive activity and anchorage-independent cell growth in lung cancer cells. The expression of REG I $\alpha$ or $R E G$ I $\beta$ in HLC- 1 REG I $\alpha / \mathrm{I} \beta$ and EBC- 1 REG I $\alpha / \mathrm{I} \beta$ cells was confirmed by real-time RT-PCR, whereas no expression of REG I $\alpha$ or REG I $\beta$ was detected in the HLC-1 and EBC-1 mock control cell lines. All of the HLC-1 REG I $\alpha / \mathrm{I} \beta$-transfected cell lines showed a significant increase in cell number when compared with the HLC-1 mock cells on culture day 7 (Fig. 1A). In contrast, HLC-1 REG I $\alpha$ cells did not show increased cell invasive activity when compared with the HLC-1 mock cells, while HLC-1 REG I $\beta$ cells in fact showed a decelerated invasive potential (Fig. 1B). HLC-1 REG I $\alpha / \mathrm{I} \beta$ cells showed significant increases in anchorage-independent cell growth as compared with the HLC-1 mock cells (Fig. 1C).

By comparison, we observed no significant increases in cell number for the EBC-1 REG I $\alpha / \mathrm{I} \beta$-transfected cells as compared with the EBC-1 mock cells after 3 days of culture (Fig. 1D). EBC-1 REG I $\alpha-2$, EBC-1 REG I $\beta-1$ and -2 cells showed increased cell invasive activity as compared with the EBC-1 mock cells (Fig. 1E), and all of the EBC-1 REG I $\alpha / \mathrm{I} \beta$ cell lines showed a significant increase in anchorage independent cell growth when compared with the EBC-1 mock cells (Fig. 1F).

REG family gene expression in normal lung and tumor tissues. Expression of all the REG family genes, except for $R E G I \beta$, was observed in both normal lung and tumor tissues (Fig. 2). REG I $\beta$ was expressed only in $3 \mathrm{AD}$ patients. The expression of REG III and HIP/PAP was noted in $\sim 90 \%$ of both normal lung and tumor tissues. The expression profile of these genes was not different between the normal lung and tumor tissues. Comparatively, REG I $\alpha$ and REG IV mRNAs were observed more frequently in tumor tissues than in normal lung tissues. Therefore, we focused on the correlation between 

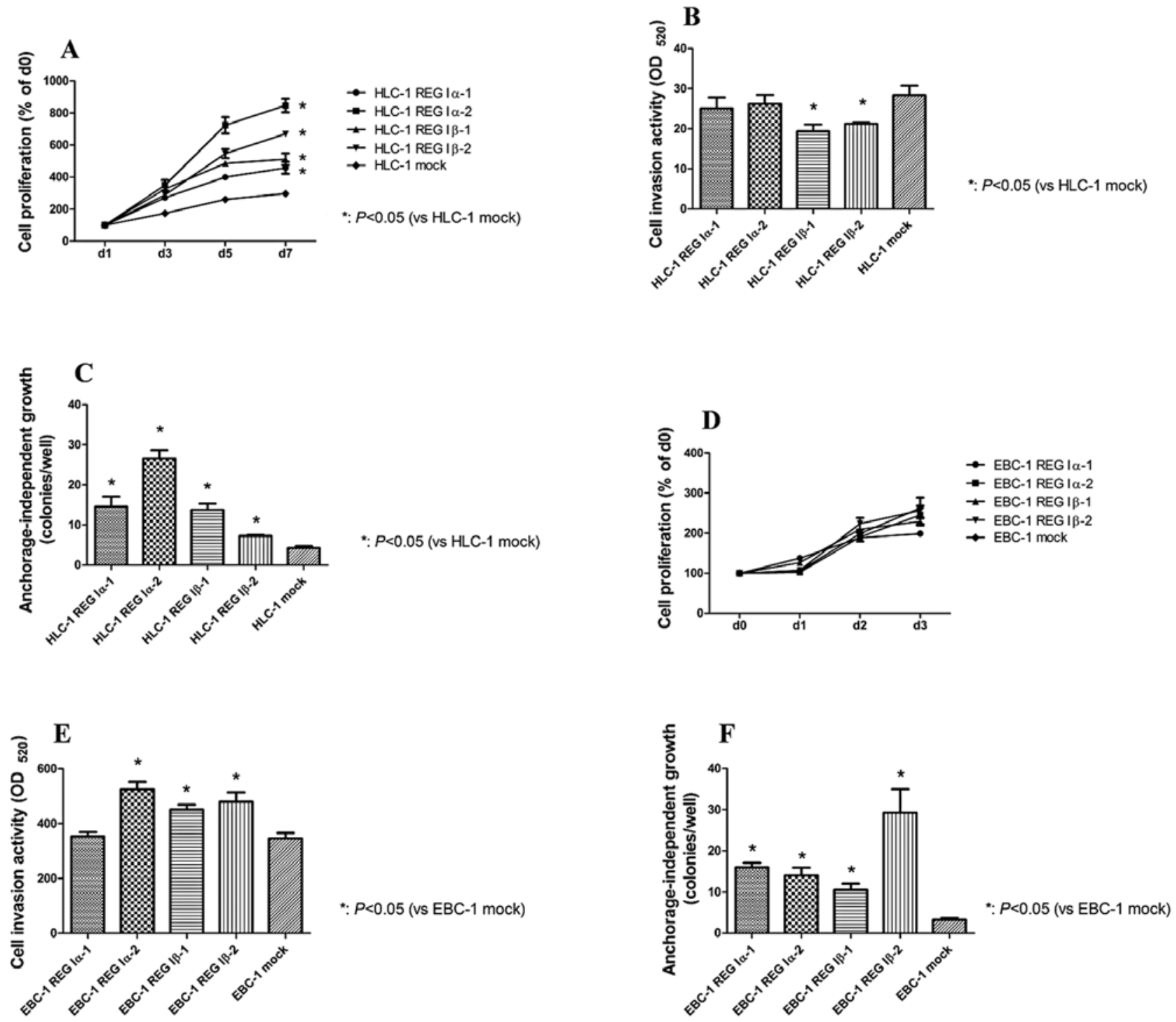

Figure 1. REG I $\alpha$ and $I \beta$ expression in lung adenocarcinoma (HLC-1) and lung squamous cell carcinoma (EBC-1) cells. Cells were stably transfected with $R E G I \alpha$ and $I \beta$. The effects of REG I $\alpha$ or $I \beta$ on proliferation (A and D), cell invasive activity (B and $\mathrm{E}$ ), and anchorage-independent cell growth (C and $\mathrm{F}$ ), HLC-1 and EBC-1 mock cells acted as mock-transfected controls.

the expression of REG I $\alpha$ and REG VI in tumor tissues and the prognosis of patients in the subsequent studies.

REG I $\alpha$ expression and prognosis of patients. In the 68 patients (AD, 47; SCC, 21) who underwent complete resection, there were no significant differences in gender, age or pathological stage between patients who were positive and those who were negative for REG I $\alpha$ expression (Table II). First, we evaluated the relationship between the expression of REG I $\alpha$ and prognosis in these 68 patients. Ten patients (AD, 5; SCC, 5) showed positive expression for $R E G I \alpha$, whereas 58 patients (AD, 42; $\mathrm{SCC}, 16)$ showed negative expression. Overall, there was no significant correlation between patients with positive or negative $R E G I \alpha$ expression and prognosis $(\mathrm{P}=0.1585$; Fig. $3 \mathrm{~A})$. However, when we examined the 46 stage I patients separately, we observed a significantly worse prognosis in patients with positive $R E G I \alpha$ expression $(\mathrm{n}=7)$ than those with negative REG $I \alpha$ expression $(\mathrm{n}=39)(\mathrm{P}=0.0009$; Fig. 3B). In addition, the 5-year survival in these patients with positive $R E G I \alpha$ expression was significantly lower than that in patients with negative $R E G I \alpha$ expression (42.9 vs. $84.9 \%$; $\mathrm{P}=0.034$ ). Next, we divided 46 stage I patients into two groups by histological types: AD $(n=32)$ and SCC $(n=14)$. The prognosis of stage I $\mathrm{AD}$ patients positive for $R E G I \alpha$ expression was significantly worse than that for patients negative for $R E G I \alpha(\mathrm{P}=0.0167$; Fig. 3C). In stage I SCC patients, however, there was a trend toward poor prognosis in patients with positive $R E G I \alpha$ expression $(\mathrm{P}=0.0551$; Fig. 3D) when compared with the negative patients. Concerning REG IV expression and patient prognosis, no correlation was noted for any of the subgroupings detailed above (data not shown).

REG I $\alpha$ expression in FFPE samples. Next, we tested REG I $\alpha$ expression in FFPE samples taken from a random selection of AD $(n=10)$ and SCC $(n=8)$ patients, and compared the results with $R E G I \alpha$ expression in surgical samples. As shown in 


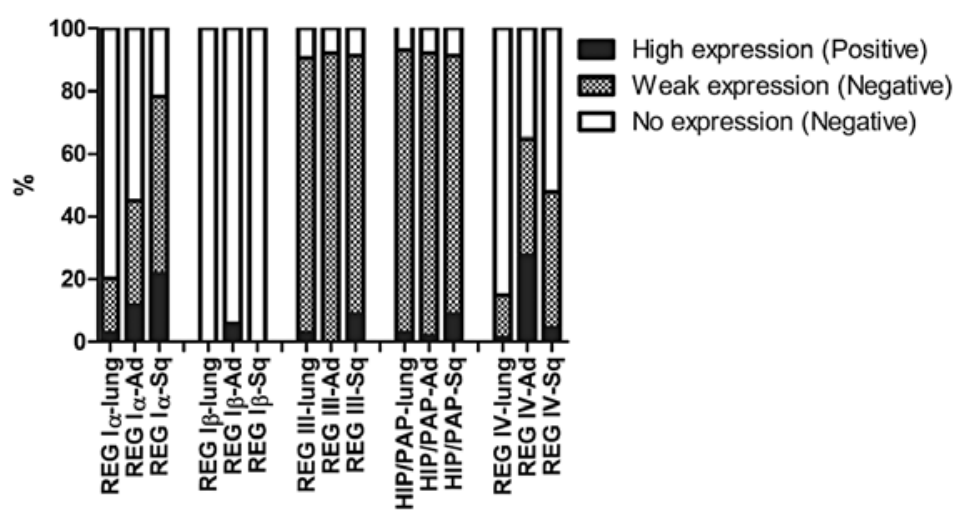

Figure 2. Expression levels of $R E G$ family genes in normal lung and tumor tissues. The cut-off levels for expression of each $R E G$ family gene were set at average $+3 \mathrm{SD}$ expression of the normal lung tissues. The expression of each $R E G$ family gene, which was higher or lower than the cut-off level, was defined as high expression (positive) or weak expression (negative), respectively. The absence of expression of each gene, was defined as no expression (negative). REG I $\alpha$-lung, $R E G$ I $\alpha$ expression in normal lung tissues; REG I $\alpha$-Ad, REG I $\alpha$ expression in AD; REG I $\alpha$-Sq, $R E G$ I $\alpha$ expression in SCC; REG I $\beta$-lung, $R E G$ I $\beta$ expression in normal lung tissues; REG I $\beta$-Ad, REG I $\beta$ expression in AD; REG I $\beta$-Sq, REG I $\beta$ expression in SCC; REG III-lung, REG III expression in normal lung tissues; REG III-Ad, REG III expression in AD; REG III-Sq, REG III expression in SCC; HIP/PAP-lung, HIP/PAP expression in normal lung tissues; HIP/PAP-Ad, HIP/PAP expression in AD; HIP/PAP-Sq, HIP/PAP expression in SCC; REG IV-lung, REG IV expression in one normal lung tissue; REG IV-Ad, REG IV expression in AD; REG IV-Sq, REG IV expression in SCC.
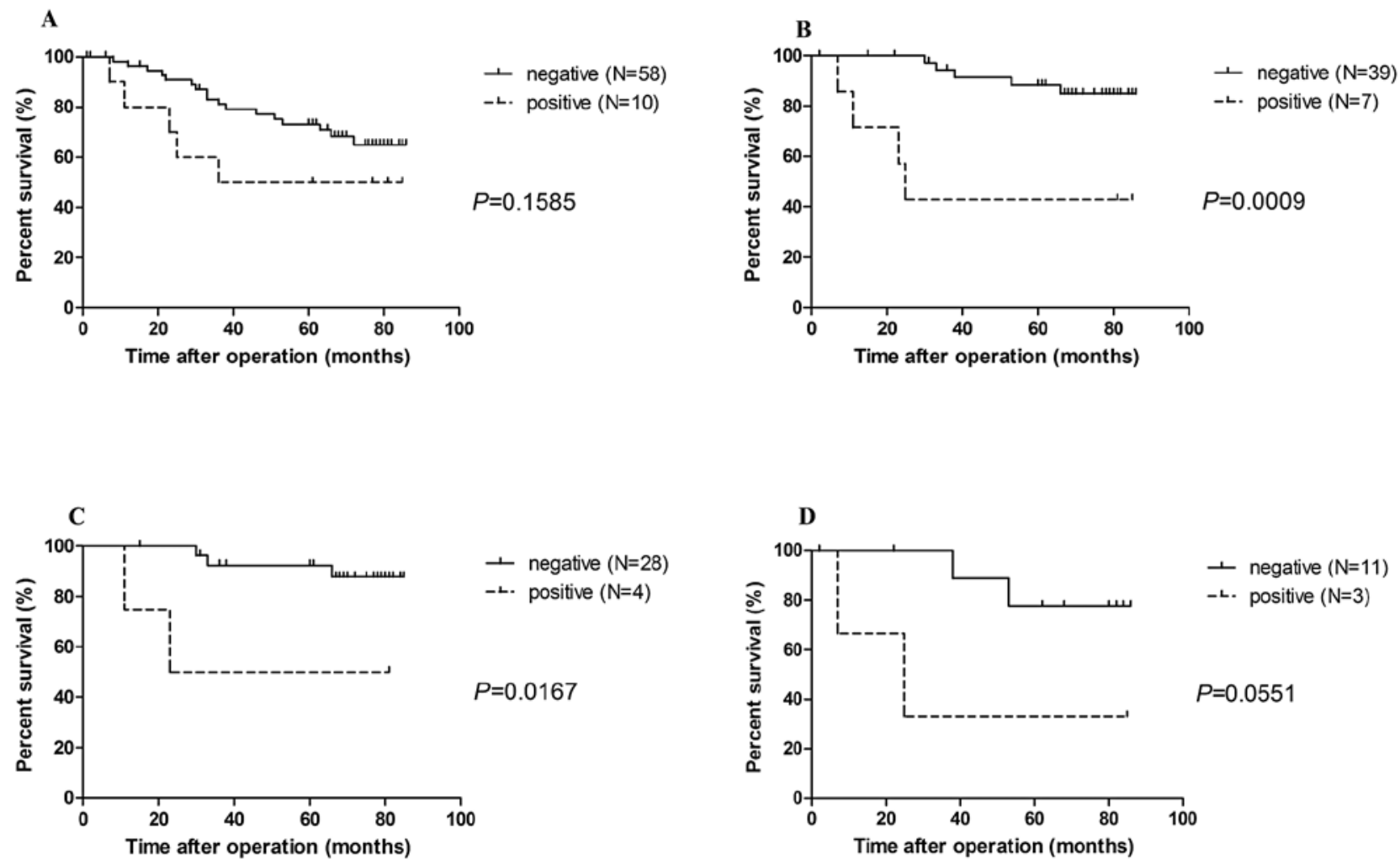

Figure 3. Disease-specific survival of patients with positive and negative expression of the REG I $\alpha$ gene. Patient death by progression of lung cancer (diseasespecific survival; DSS) was defined as the end point. DSS of patients with positive and negative expression for REG Ia in (A) all patients, (B) stage I patients, (C) stage I adenocarcinoma patients and (D) stage I squamous cell carcinoma patients.

Fig. 4, a significant correlation was noted between $R E G I \alpha$ expression from the surgical samples and that from the FFPE samples (Pearson correlation $\mathrm{r}=0.9475)$.

\section{Discussion}

The effect of $R E G$ family genes on malignancies has been studied mainly in gastrointestinal cancers $(10-15,17-20)$.
REG I $\alpha$ and REG IV was found to be correlated with poor prognosis in gastric and colorectal cancers $(12-15,27)$. A correlation, however, has recently been reported to exist between high expression of REG $I \alpha$ and a more favorable prognosis in esophageal cancer patients (18). The authors indicated that high expression of $R E G I \alpha$ enhanced the chemosensitivity and radiosensitivity of esophageal cancer cells, which may explain the better prognosis of the patients (17). This high expression 


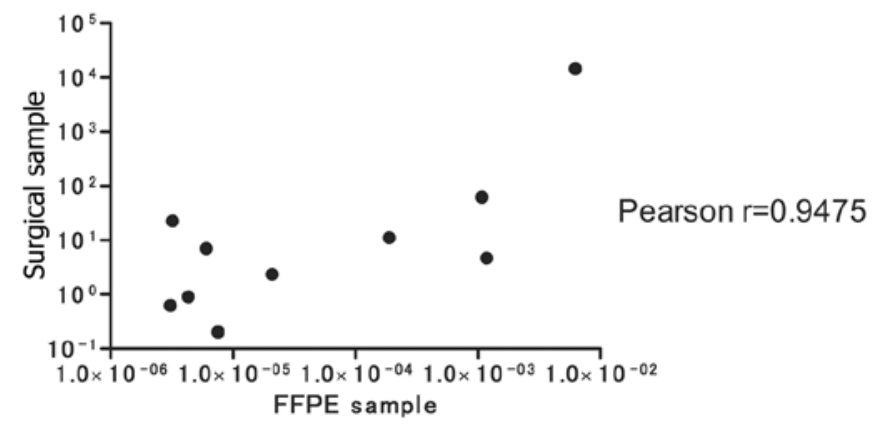

Figure 4. Correlation of the expression of REG I $\alpha$ from surgical and FFPE samples. A significant correlation was noted between the expression of $R E G I \alpha$ in surgical and FFPE samples (Pearson $\mathrm{r}=0.9475$ ).

is contradictory to the findings of others (14-16,26-28), but may be explained by histopathological differences between other gastrointestinal tumors and esophageal tumors; most esophageal cancers are SCCs, whereas other gastrointestinal cancers are ADs. Gastric AD patients with REG I $\alpha$ expression were reported to show poor prognosis, and REG I $\alpha$-expressing cells exhibit an increase in cell number (13). In lung cancer, the reason why $R E G I \alpha$ expression leads to a poorer prognosis has not been clarified (28). We hypothesized that discrete mechanisms may exist in lung cancer cells due to histological distinctions between AD and SCC cells. Thus, we performed an in vitro study to clarify the effect of the expression of $R E G I \alpha$ and $R E G I \beta$, which has a similar structure to $R E G I \alpha$ and seems to have an identical function to $R E G I \alpha$, on $\mathrm{AD}$ and SCC cells.

In $\mathrm{AD}$ cells, both REG I $\alpha$ and $I \beta$ increased cell numbers as compared with the control cells, whereas, in SCC cells, neither $R E G I \alpha$ nor $I \beta$ influenced cell number. In contrast, no clear effect was found in the AD cells in regards to enhanced cell invasion in response to either gene, whereas a positive effect was demonstrated in SCC cells. Anchorage-independent cell growth, however, was upregulated for both cell types expressing $R E G I \alpha$ and $I \beta$. These results suggest that the effect of $R E G I \alpha$ and $I \beta$ on lung cancer is specific in regards to the type of tumor. From these results, we hypothesized that patients who express the $R E G I \alpha$ and $I \beta$ genes may have poor prognosis by different mechanisms as described above. We evaluated the relationship between the expression of these genes and patient prognosis.

Despite recent findings that a link exists between the $R E G$ family genes and various significant cancer subtypes (10-27), including lung cancer (28), the expression levels of this family of genes have not been explored. In the present study, we evaluated the expression levels of $R E G$ family genes in lung cancer tissues. Almost all of the REG family genes were expressed both in normal lung and tumor tissues except for $R E G I \beta$. However, positive ratios of gene expression levels varied for each $R E G$ family member. REG III and HIP/PAP were high in both normal lung and tumor tissues. Conversely, the expression ratios of $R E G I \alpha$ and $R E G I V$ in tumor tissues were higher than those in normal lung tissues. Previous studies have shown that prognoses are worse in patients with stomach, pancreatic, lung, and breast cancers with high REG I $\alpha$ expression (14-16,26-28). Likewise, high REG IV expression in colorectal and prostate cancers is linked with a worse prognosis $(12,24)$. Therefore, we also tested correlations between the expression of REG $I \alpha$ and $R E G I V$ and patient prognosis in lung cancer patients. We found that a high expression of $R E G I \alpha$ was correlated with poor prognosis in stage I lung cancer patients, suggesting that $R E G I \alpha$ is a reliable marker for the prognosis of stage I lung cancer patients. The in vitro study confirmed that the REG I $\beta$ gene promoted an increased cell number and anchorage-independent cell growth in AD cells, and increased cell invasive activity and anchorage-independent cell growth in SCC cells. However, REG I $\beta$ was expressed only in $3 \mathrm{AD}$ patients. Therefore, the expression of the REG I $\beta$ gene seems to have no meaning clinically. Together with the in vitro data, we surmised that poorer prognosis in $R E G I \alpha$-expressing AD patients stems from an increase in cell number and anchorageindependent cell growth, whereas the tendency for a poorer prognosis in SCC patients with positive expression of $R E G I \alpha$ might be due to enhanced cell invasion and anchorage-independent cell growth. In comparison, we found no correlation between $R E G I V$ and prognosis, suggesting a different role for $R E G I V$ in lung cancer $(12,24)$.

As it is not easy to obtain fresh frozen surgical samples, we also evaluated the expression of the $R E G I \alpha$ gene in FFPE samples to compare an easier, more practical and more economical method for RNA extraction for future clinical applications. We found a significant correlation in $R E G I \alpha$ expression between the two different sampling and real-time RT-PCR methods (Fig. 4). Clinically, the positive effect of $R E G I \alpha$ in lung cancer cells implies that $R E G I \alpha$ could be used as an indicator to initiate adjuvant therapy, even in stage I lung cancer patients; alternatively, it may become a target for therapy or a marker of chemosensitivity and radiosensitivity (18).

One of the limitations of the present study was the small number of participants in the SCC group, as the correlation between $R E G I \alpha$ and prognosis could only be evaluated in 14 stage I SCC patients. This may explain the lack of a significant correlation between the expression of REG I $\alpha$ and SCC prognosis.

In summary, the REG I $\alpha$ gene increased the cell number and anchorage-independent cell growth of lung adenocarcinoma cells, and the cell invasive activity and anchorage-independent cell growth in lung squamous cell carcinoma. Overexpression of the REG I $\alpha$ gene is a risk factor for poor prognosis in lung cancer patients functioning via different mechanisms in adenocarcinoma and squamous cell carcinoma.

\section{Acknowledgements}

We are grateful to Dr Maiko Takeda and Dr Takahiko Kasai, Nara Medical University School of Medicine for their kind assistance. The present study was for partial academic fulfillment of the degree thesis by M.K. of Medical Science at Nara Medical University. The study was also supported in part by grants-in-aid for Scientific Research (Practical Application Research) from the Japan Science and Technology Agency.

\section{References}

1. Cancer statistics in Japan '08. November 5, 2008. Available at: http://ganjoho.jp/pro/statistics/en/gdb_year.html?1\%1. Accessed July $24,2012$. 
2. Whitson BA, Groth SS, Duval SJ, Swanson SJ and Maddaus MA Surgery for early-stage non-small cell lung cancer: a systematic review of the video-assisted thoracoscopic surgery versus thoracotomy approaches to lobectomy. Ann Thorac Surg 86: 2008-2016, 2008.

3. Wright G, Manser RL, Byrnes G, Hart D and Campbell DA: Surgery for non-small cell lung cancer: systematic review and meta-analysis of randomised controlled trials. Thorax 61: 597-603, 2006

4. Mountain CF: Revisions in the International System for Staging Lung Cancer. Chest 111: 1710-1717, 1997.

5. Ginsberg RJ and Rubinstein LV: Randomized trial of lobectomy versus limited resection for T1 N0 non-small cell lung cancer. Lung Cancer Study Group. Ann Thorac Surg 60: 615-622, 1995.

6. Terazono K, Yamamoto H, Takasawa S, et al: A novel gene activated in regenerating islets. J Biol Chem 263: 2111-2114, 1988.

7. Watanabe T, Yonemura Y, Yonekura H, et al: Pancreatic beta-cell replication and amelioration of surgical diabetes by Reg protein Proc Natl Acad Sci USA 91: 3589-3592, 1994.

8. Takasawa S, Ikeda T, Akiyama T, et al: Cyclin D1 activation through ATF- 2 in Reg-induced pancreatic $\beta$-cell regeneration. FEBS Lett 580: 585-591, 2006.

9. Nata K, Liu Y, Xu L, et al: Molecular cloning, expression and chromosomal localization of a novel human $R E G$ family gene, REG III. Gene 340: 161-170, 2004.

10. Sekikawa A, Fukui H, Fujii S, et al: REG I $\alpha$ protein may function as a trophic and/or anti-apoptotic factor in the development of gastric cancer. Gastroenterology 128: 642-653, 2005.

11. Mitani Y, Oue N, Matsumura S, et al: Reg IV is a serum biomarker for gastric cancer patients and predicts response to 5-fluorouracil-based chemotherapy. Oncogene 26: 4383-4393, 2007.

12. Oue N, Kuniyasu H, Noguchi T, et al: Serum concentration of Reg IV in patients with colorectal cancer: overexpression and high serum levels of Reg IV are associated with liver metastasis. Oncology 72: 371-380, 2007.

13. Fukui H, Fujii S, Takeda J, et al: Expression of REG I $\alpha$ protein in human gastric cancers. Digestion 69: 177-184, 2004.

14. Yamagishi H, Fukui H, Sekikawa A, et al: Expression profile of REG family proteins REG I $\alpha$ and REG IV in advanced gastric cancer: comparison with mucin phenotype and prognostic markers. Mod Pathol 22: 906-913, 2009.

15. Dhar DK, Udagawa J, Ishihara S, et al: Expression of regenerating gene I in gastric adenocarcinomas: correlation with tumor differentiation status and patient survival. Cancer 100: 1130-1136, 2004.

16. Sasaki Y, Minamiya Y, Takahashi N, et al: REG1A expression is an independent factor predictive of poor prognosis in patients with breast cancer. Ann Surg Oncol 15: 3244-3251, 2008.
17. Hayashi K, Motoyama S, Koyota S, et al: REG I enhances chemo- and radiosensitivity in squamous cell esophageal cancer cells. Cancer Sci 99: 2491-2495, 2008.

18. Hayashi K, Motoyama S, Sugiyama T, et al: REG I $\alpha$ is a reliable marker of chemoradiosensitivity in squamous cell esophageal cancer patients. Ann Surg Oncol 15: 1224-1231, 2008.

19. Motoyama S, Sugiyama T, Ueno Y, et al: REG I expression predicts long-term survival among locally advanced thoracic squamous cell esophageal cancer patients treated with neoadjuvant chemoradiotherapy followed by esophagectomy. Ann Surg Oncol 13: 1724-1731, 2006.

20. Usami S, Motoyama S, Koyota S, et al: Regenerating gene I regulates interleukin-6 production in squamous esophageal cancer cells. Biochem Biophys Res Commun 392: 4-8, 2010.

21. Kiji T, Dohi Y, Takasawa S, Okamoto H, Nonomura A and Taniguchi S: Activation of regenerating gene Reg in rat and human hearts in response to acute stress. Am J Physiol Heart Circ Physiol 289: H277-H284, 2005.

22. Kiji T, Dohi Y, Nishizaki K, et al: Enhancement of cell viability in cryopreserved rat vascular grafts by administration of regenerating gene (REG) inducers. J Vasc Res 40: 132-139, 2003.

23. Harada K, Zen Y, Kanemori Y, et al: Human REG I gene is up-regulated in intrahepatic cholangiocarcinoma and its precursor lesions. Hepatology 33: 1036-1042, 2001.

24. Ohara S, Oue N, Matsubara A, et al: Reg IV is an independent prognostic factor for relapse in patients with clinically localized prostate cancer. Cancer Sci 99: 1570-1577, 2008.

25. Zhou L, Zhang R, Wang L, et al: Upregulation of REG I $\alpha$ accelerates tumor progression in pancreatic cancer with diabetes. Int $\mathrm{J}$ Cancer 127: 1795-1803, 2010.

26. Yonemura Y, Sakurai S, Yamamoto H, et al: REG gene expression is associated with the infiltrating growth of gastric carcinoma. Cancer 98: 1394-1400, 2003.

27. Zheng HC, Sugawara A, Okamoto H, et al: Expression profile of the REG gene family in colorectal carcinoma. J Histochem Cytochem 59: 106-115, 2011.

28. Minamiya $\mathrm{Y}$, Kawai $\mathrm{H}$, Saito $\mathrm{H}$, et al: REG1A expression is an independent factor predictive of poor prognosis in patients with non-small cell lung cancer. Lung Cancer 60: 98-104, 2008.

29. Takasawa S, Kuroki M, Nata K, et al: A novel ryanodine receptor expressed in pancreatic islets by alternative splicing from type 2 ryanodine receptor gene. Biochem Biophys Res Commun 397: $140-145,2010$

30. Ota H, Tamaki S, Itaya-Hironaka A, et al: Attenuation of glucose-induced insulin secretion by intermittent hypoxia via down-regulation of CD38. Life Sci 90: 206-211, 2012.

31. Masui T, Ota I, Itaya-Hironaka A, et al: Expression of REG III and prognosis in head and neck cancer. Oncol Rep 30: 573-578, 2013. 